\title{
David J. Smith
}

\section{December 1923-24 November 2016}

David Smith, who has died at the age of 92, was one of the last survivors of the group of British archaeologists who, working under the leadership of Richard Goodchild and Bryan Ward-Perkins, made a significant contribution to the development of Libyan archaeology in the decade following the Second World War as the country gained its full independence.

Although he was born and educated in north-east England and spent almost his entire working life at the University of Newcastle, his Libyan adventures represent a remarkable interlude. His university education at King's College, Newcastle (later to become the University of Newcastle), was interrupted by wartime service and it was his experience of Roman ruins in Tunisia that was to set his life course. When he returned to complete his degree, he soon made Roman archaeology his specialism under Ian Richmond's guidance, following up with a $\mathrm{PhD}$ at Durham on Roman mosaics in Britain (awarded in 1952).

Richmond subsequently found him work setting up a number of the north-eastern museums, notably
South Shields and the Museum of Antiquities at the University of Newcastle, where by 1956 he had been appointed permanent Custodian and Secretary of the Collections (later also becoming a member of the academic staff at the Department of Archaeology when it was established in 1972). He spent the rest of his career there, retiring in 1987 as Senior Lecturer. He was a meticulous scholar, but modest and unassuming in his personal dealings - yet in his quiet way his career achieved considerable impacts.

His academic research was primarily in the field of mosaic studies (see further below). However, the interest in North Africa sparked by his wartime experience led to significant engagement in Libyan archaeology, especially during the 1950s. He was a prominent member of the 'Mapping Roman Libya' expedition led by Richard Goodchild in 1950-51 (successively its quartermaster and deputy director) and he also led a University of Durham expedition to French Morocco in 1952. Most important though was his collaboration with Olwen Brogan from 1955 to 1958 at the Romano-Libyan settlement of Ghirza

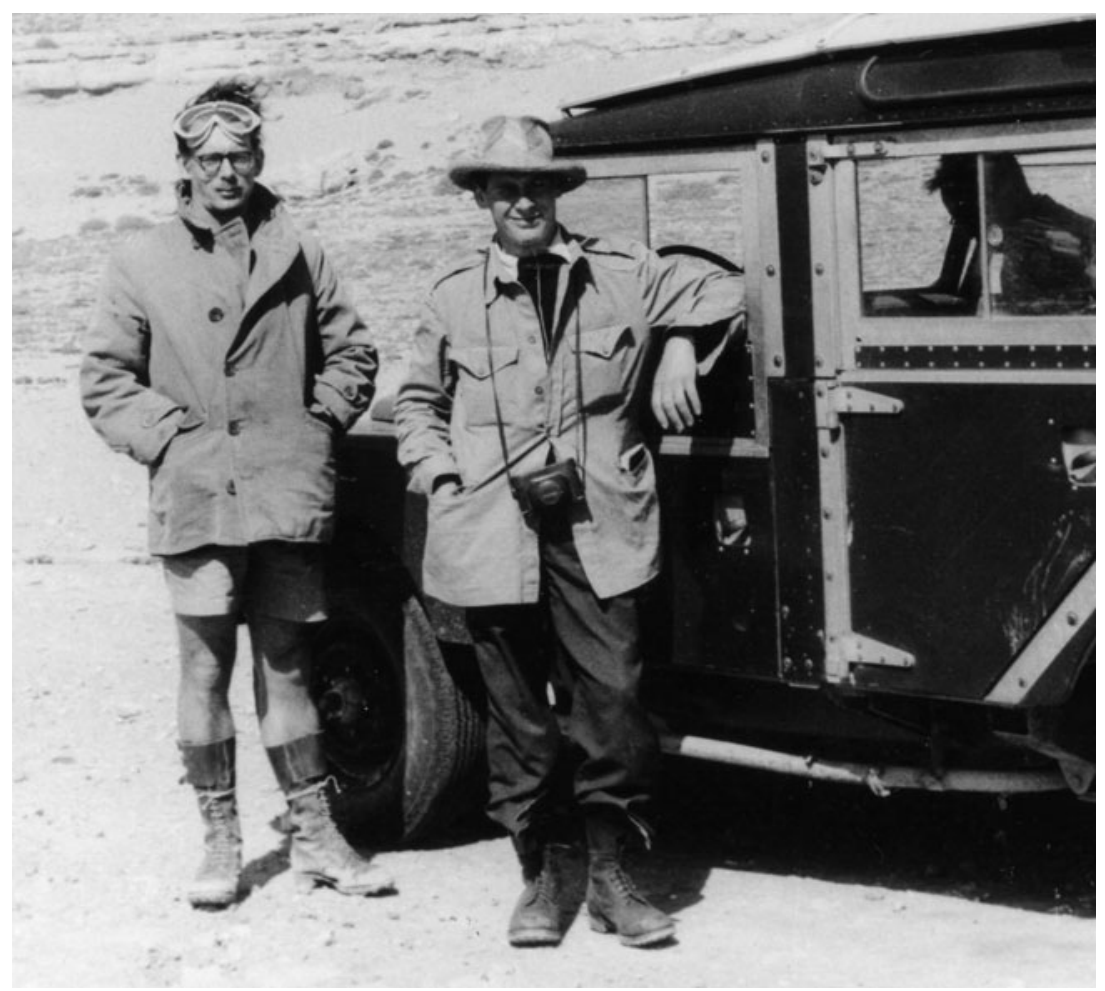

Figure 1. David Smith (left) and Charles Daniels, en route to Fazzan in 1958. 
in the Tripolitanian pre-desert. Their project, involving survey and selective excavation, remains a key publication on the cultural identity of a Libyan rural farming community (Brogan and Smith 1984). David took prime responsibility for the study of the settlement's buildings, many fortified in nature, while Olwen concentrated on the study of elaborate mausolea. He also excavated the settlement's main temple - still a rare excavated example of a rural religious shrine in Tripolitania (though he was disappointed in his initial hope that it would prove to be a church that was subsequently turned into a mosque). $\mathrm{He}$ and Olwen were also the mentors of the young Charles Daniels, accompanying him on his first expedition to Fazzan in 1958 - thus opening another important chapter in British work in Libya.

David Smith returned to Libya in 1966-67, directing expeditions to the Cyrenaican coastal city of Taucheira (Tocra). An important study of the town walls was later published in Libyan Studies (Smith and Crow 1998). The death of Richard Goodchild in 1968 and the Libyan Revolution in 1969 marked the effective end of his fieldwork in Libya, though he was by then heavily committed to other research. Though he closely followed events in Libya and matters relating to the Society for Libyan Studies in his correspondence with Olwen and through his colleague Charles Daniels, he never seems to have served on the Society's Council.

In the field of mosaics, he was, however, deeply involved in the birth of a major international initiative: the Association Internationale pour l'Étude de la Mosaïque Antique, in 1963. Then in 1978 he was responsible for the founding of its British branch, the Association for the Study and Preservation of Roman Mosaics. Both organisations continue to flourish. $\mathrm{He}$ was also part of a group of international scholars who, from the 1950s, developed the study of mosaics and demonstrated its value as a topic in its own right. His contribution was focused on Britain - he did not

University of Leicester, UK King's College London, UK publish on the mosaics of North Africa - where he made major advances in the material and visual analysis of mosaics, concerning himself with understanding their place in architectural, social and provincial contexts. He was particularly interested in design and decoration, precisely mapping workshop production across Britain, especially in the second and fourth centuries AD. He published widely, writing important syntheses while also being involved in major finds and contributing numerous reports (see Witts 1998). His scholarship significantly increased our knowledge of artistic developments in Romano-British society and continues to sit at the heart of mosaic studies, both in Britain and internationally.

A final contribution of David Smith needs to be celebrated in this journal. He took the decisive initiative at the time of his own retirement and the death of Olwen Brogan in the late 1980s to get the Society to establish its archive, based initially in Newcastle and formed around the core of their joint papers. David was notoriously shy of cameras and we had to search long and hard to locate a recognisable portrait in the archive. However, his voluminous correspondence with Olwen Brogan sheds interesting light on the trials and tribulations of funding on a shoestring the fieldwork and post-excavation study of Ghirza. David's notebook entries also capture, in a characteristically succinct and terse style, a lost age, with so much left unsaid in between the lines:

Sat 19/5/56 [having just arrived at Ghirza] Tour of site occupied morning. Olwen went to find workmen. I went to look for airfield and help lay out airstrip.

Sun 20/5/56 Two officers and two professors departed in the morning. Aircraft didn't come. Ghibli began. (Smith notebook, 1956)

The archive will preserve the memory of these contributions that truly belong to a lost and pioneering age of Libyan archaeology.

David Mattingly Will Wootton

\section{References}

Brogan, O., and Smith, D. J. 1984. Ghirza: A Romano-Libyan Settlement in Tripolitania. Libyan Antiquities Series 1. Tripoli.
Smith, D., and Crow, J. 1998. The Hellenistic and Byzantine defences of Tocra (Taucheira). Libyan Studies 29: 35-82.

Witts, P. 1998. Dr David Smith. Mosaic 25: 4-8. 